DOI: 10.14526/2070-4798-2020-15-2-5-8

\title{
World Ethnosport Confederation Traditional Sports and Games Research Executives (TSGREs) $2^{\text {nd }}$ Meeting Notes
}

\author{
M.Levent Akici, Zinaida M. Kuznetsova*, Elena A. Kuznetsova \\ Director of Sports and Corporate Relations of WEC (Turkey) \\ Naberezhnye Chelny branch of Management University "TISBI” \\ Naberezhnye Chelny, Russia \\ ORCID: oooo-ooo2-5558-474X,kzm_diss@mail.ru* \\ ORCID: oooo-0oo2-5983-0848, journal@list.ru
}

$\underline{\text { Review article }}$

The $2^{\text {nd }}$ meeting of WEC Traditional Sports and Games Research Executives had one session. The agenda of the meeting consisted of the following subjects:

1- Presentation of the draft methodology and framework for the Leading Group and Working Group

2- Ideas for structuring the methodology and framework for the Groups

3- Announcement of the CV collection deadline for the Working Group

The meeting started with welcoming and introduction of WEC Education Commission by Prof Dr Ocal Oguz, the Chairman of the WEC Education Commission. Mr. Oguz briefed the participants about the WEC Education Commission and its commitments. He explained WEC Education Commission by seven working axis.

1. Forming the WEC PhD Scholarships to the students who currently do their PhD in TSG field.

2. Providing academic article incentives for the publications on prestigious bulletins

3. Working Group initially structures a list of traditional sports and games starting from WEC member countries

4. The digital entry of these sports and games will be done on digital system

5. Similar sports and games from the close geographies will be aimed to get together on festival, events, and organizations etc.
6. Likewise, Mangala, which the common file was presented to UNESCO by Turkey, Kyrgyzstan, Kazakhstan and Azerbayzgan, Similar sports and games authorities could write a common file to UNESCO about their games if they want to

7. Creating a digital encyclopedia that contains related photos and videos of the sports and games as one of the purposes

Mr Oguz emphasized that the Leading Group is here to function as a consultant group to support Working Group which is headed by Ms Zeynep Nalcioglu.

Mr Akici continued the meeting by presenting Draft file of Methodology and Framework for the Groups which covers the four main subjects (Priorities, Framework of the Leading Group, Framework of the Working Group and Theme of Study). He presented the following to the participants. 


\begin{tabular}{|c|c|}
\hline Purpose & esearch, collect and digitalize the TSGs of the world. \\
\hline Goal & $\begin{array}{l}\text { A pre-work (publication) that would contribute to the creation of World TSG } \\
\text { Encyclopedia (World Ethnosport Encyclopedia) }\end{array}$ \\
\hline Priorities & $\begin{array}{l}\text { 1. Aligning and tracking the purpose and goal above in accordance with the } \\
\text { declaration of the } 3^{\text {rid }} \text { Ethnosport Forum } \\
\text { 2. Reaching the most correct information in the research by scanning the related } \\
\text { resources } \\
\text { 3. Making the field research if needed to check the information found } \\
\text { 4. Collecting the information step by step and diversifying the groups over time } \\
\text { 5. Being transparent and caring about the copy-rights issues of the research } \\
\text { 6. Digitalizing the information collected } \\
\text { 7. Coordinating with the universities or institutes for cooperation and network } \\
\text { 8. Collaborating with TSG federations-associations and NGOs } \\
\text { 9. Informing the related government bodies about the research to establish } \\
\text { awareness } \\
\text { 10. Promoting the efforts on digital medias } \\
\text { 11. Motivating and favoring the new academicians } \\
\text { 12. Promoting the contributors } \\
\text { 13. Making regular meetings to review the outcomes and process } \\
\text { 14. Supporting the academic part of the Ethnosport Forums to form new action plans }\end{array}$ \\
\hline $\begin{array}{l}\text { Framework } \\
\text { of the } \\
\text { Leading } \\
\text { Group }\end{array}$ & $\begin{array}{l}\text { 1- Identifying the steps and template of the research (three division approach: } \\
\text { existing, known but not played, forgotten - draft template in the bottom) } \\
\text { 2- Determining the framework and the methodology of the studies requested from } \\
\text { the Working Group } \\
\text { 3- Providing related materials and resources to the Working Group for efficient and } \\
\text { productive research outcomes } \\
\text { 4- Checking, reviewing and advising for the studies/works of the Working Group } \\
\text { 5- Guiding the Working Group to accumulate knowledge and sharing research } \\
\text { experiences } \\
\text { 6- Keeping direct contact with the Working Group Members } \\
\text { 7- Representing the WEC TSG Executives group in different academic stages }\end{array}$ \\
\hline $\begin{array}{l}\text { Framework } \\
\text { of the } \\
\text { Working } \\
\text { Group }\end{array}$ & $\begin{array}{l}\text { 1- For the beginning there will be selected a couple of members for the group } \\
\text { 2- Analyzing and gathering information on TSGs by country-region from an } \\
\text { academic perspective. } \\
\text { 3- Editing and finalizing the studies within the designated framework by the } \\
\text { Leading Group. } \\
\text { 4- Consulting the Leading Group members for deepening and widening their } \\
\text { research } \\
\text { 6- Will be responsible to the facilitator of the Working Group in research manners } \\
\text { 6- Accumulating, generating and classifying the information will be the priority }\end{array}$ \\
\hline
\end{tabular}

THEME OF THE STUDY

\begin{tabular}{|l|l|}
\hline \multicolumn{1}{|c|}{ Abstract } & \\
\hline History and Importance for the Public of the Sport or Game & \\
\hline Rules of The Sport or Game & \\
\hline Locations & \\
\hline Benefits to the Body or Intelligence & \\
\hline Cultural Codes of the Sport or Game & \\
\hline Related Events & \\
\hline Responsible Institution & \\
\hline Photos & \\
\hline Resources & \\
\hline
\end{tabular}




\section{Notes from Participants:}

Dr. Lahgla Bouzid evaluated the presentation shorty and added the ideas of structuring the Working Group based on geographical nearness. He also said the research would be done by categories to be played at schools.

Prof. Dr. Mr Yaici agreed with the prestntation and emphasized the importance of creating the Charter of Ethics and Professional Conducts to the Researchers regarding the $5^{\text {th }}$ subject of Priorities on the presentation.

Dr. Stefan Krist agreed the articles of the presentation and emphasized the importance of reaching the most reliable information by doing the field research and collaborating with government authorities, NGOs and universities.

Dr. Kazimierz Waluch emphasized the importance of the fieldwork during the research

Prof Dr Zinaida Kuznetsova said that the draft presentation was good and she added that the research process could be started from the traditional sport Kuresh. Moreover, she reminded a conference devoted to sports would held in Russia 24 September 2020. She invited to take part in the conference.

Dr Feruze Djumaniyazova said that the draft presentation seems well-structured.

Dr Inga Mendot said in Tuva there are many sports including wresting, horse games and archery.

Prof. Dr. Elemes Alimkhanov suggested the research should be done withing a time a plan work frame.

Prof. Dr. Mehmet Turkmen emphasized that the meaning of sport included many common values in many dimensions. Traditional wresting for instance in Turkey or in India has similarities in symbolic meanings and implementation. When the research is done it will be continued respectfully to others because each sports or game has a national essence.

Prof. Dr. Muhsin Hazar mentioned these researches would be a record to thehistory. Compiling and registering a sport or game is important by doing a good research. In this regard, reaching out more information along with sociological and anthropological data and in the field work is crucial. Furthermore, he said the sustainability and practice of the sports was in need.

Prof. Dr. Mehmet Barca mentioned that there might be written additional subject to the Theme of Research that shows the differences of the sports and games between countries and the material of the sports. Moreover, he mentioned that the name of the group could be changed into Research and Education which includes four sub-committees. 1- Academic Research Sub-committee engages with scholarships, academic articles, and bulletin. 2Education Research Sub-Committee engages with introducing the traditional sports and games to the schools curriculums at all levels. 3- Encyclopedia sub-committee engages with designating the writing guideline, subjects and classification 4- Introduction tool committee engages with writing textbook and spreading this especially at schools via education.

Zeynep Nalcioglu reminded the participants the CV collection for the Working Group and said that in couple of weeks the election of the Working Group would be made and would begin the research process.

Prof. Dr. Ocal Oguz had his closing remarks for the meeting. He thanked everyone for being in the meeting.

Mr Akici thanked everyone for participating to the meeting. He said that the meeting notes would be deliverd to the members of the TSGREs shortly by email and on whats up group. He said that the secretariat would be waiting each participants biography with his/her related studies in the TSG field. He said that the next and important step for the TSGREs was to form the Working Group therefore the secretariat would be waiting candidate CVs from the group.

Participants of the meeting: Prof. Dr. M. Ocal Oguz - WEC Board Member, President of Turkish National Commission for UNESCO, Ms Zeynep Nalcioglu - WEC Board Member, A. Halim Aksu - Secretary General of WEC, M. Levent Akici Director of Sports and Corporate Relations of WEC, Prof. Dr. Alpaslan Ceylan, Prof. Dr. Muhsin Hazar, Prof. Dr. Mehmet Barca, Prof. Dr. Mehmet Turkmen, Prof. Dr. Ms Zinaida Kuznetsova, Dr. Feruze Djumaniyazova, Prof. Dr. Yelemes Alimkhanov, Dr. Kazimierz Waluch, Prof. Dr. Farid Yaici, Dr. Laghla Bouzid, Dr. Stefan Krist, Dr. Ms Inga Mendot. 
The meeting ended with the good wishes from every member.

Submitted: 15.05.2020

M.Levent Akici - Director of Sports and Corporate Relations of WEC (Turkey), e-mail: levent.akici@ worldethnosport.org

Zinaida M. Kuznetsova - Doctor of Pedagogics, Professor, Naberezhnye Chelny branch of Management University “TISBI", 423806, Russia, Naberezhnye Chelny, Komsomolskaya nab., House 6, e-mail: kzm diss@mail.ru

Elena A. Kuznetsova - Candidate of Pedagogics, Associate Professor, Naberezhnye Chelny branch of Management University “TISBI”, 423806, Russia, Naberezhnye Chelny, Komsomolskaya nab., House 6, e-mail:journal@list.ru 